\title{
Appraising Forest-Based Livelihoods through Assessment of Major NTFPs: A Case Study from Jharkhand, India
}

\author{
Sunil Prasad ${ }^{1 *}$ and Dhanpal Singh Chauhan ${ }^{2}$
}

\author{
${ }^{1}$ Ecology and Biodiversity Services (EBS), Indraprasth-1, Ring Road Dehradun, Uttarakhand (248 014), India \\ ${ }^{2}$ HNB Garhwal University, Srinagarh Garhal Uttarakhand (249 161), India
}

\section{Corresponding Author}

Sunil Prasad

e-mail: ebsddn@gmail.com

\author{
Article History \\ Article ID: IJEP0353 \\ Received in $27^{\text {th }}$ December, 2019 \\ Received in revised form $09^{\text {th }}$ March, 2020 \\ Accepted in final form $23^{\text {rd }}$ March, 2020
}

\begin{abstract}
The state Jharkhand is one of the Non-Timber Forest Products (NTFPs) rich states of the country because of diverse physiographic and climatic conditions. It is known for its mineral wealth, tribal population and forests. NTFPs play an important role in supporting rural livelihoods and food security in tribal Jharkhand. The present study was carried out in three distinct villages of Jharkhand to explore the range of livelihood contributions of NTFPs. The study was based on empirical fieldwork using both quantitative and qualitative data. A structured interview schedule was managed for the respondents. Comparing income sources, we found that most of the households collect NTFPs and earn a handsome amount of income from NTFPs ranges from 33\% to 59\%. We also prioritized potential NTFPs along with their basic value chain.
\end{abstract}

Keywords: Jharkhand, livelihood, NTFPs, value chain

\section{Introduction}

Of the total population of Jharkhand state, around $75.95 \%$ live in the villages of rural areas, $26.34 \%$ population of which is tribal. 35 lakhs families are below the poverty line out of the total number of about 69 lakh households. The total net sown area is only $28 \%$ of the geographical area of the state due to undulating terrain, whereas the total irrigated area is only $12.77 \%$ of the net sown area and the rain is very undependable (Jharkhand 12th Five-year plan). Jharkhand is an important State from the viewpoint of tribal population in India and around 35 types of Scheduled Tribes live in Jharkhand (Minz and Hansda, 2010). The tribal population of Jharkhand is concentrated mainly in Chhotanagpur plateau (Ranchi, Hazaribag, Giridih, Palamau, Dhanbad, Bokaro and Singhbhum districts) and Santhal Parganas. Although Jharkhand is one of the most prolific mineral states in the country, the sector have not been able to recompense tribal people properly. Tribal people are still dependent on a variety of natural resources for sustaining their lives; non-timber forest products (NTFPs) are one of these. Shaanker et al., (2004) estimated that in India alone over 50 million people are dependent on NTFPs for their subsistence and cash livelihoods. These NTFPs contribute about 20 to $40 \%$ to the annual income of tribal people who are socially and economically deprived and having very less landholding (Verma and Paul, 2016).

Jharkhand is a forest state and based on the interpretation of IRS Resourcesat-2 LISS III satellite data of the period Nov 2017 to Jan 2018, the Forest Cover in the State is $23,611.41$ sq km which is $29.62 \%$ of the State's geographical area. Forest Cover in the State has increased by $58.41 \mathrm{sq} \mathrm{km}$ as compared to the previous assessment reported in ISFR 2017 (FSI, 2019). These forests have enormous potential of producing NTFP and are capable to make a strong contribution to tribal income. The NTFPs play a central role in the socio-economic, cultural and political systems of tribal societies and the entire lives and livelihoods of these people revolve around forests and forestry (Bedia, 2014). Islam and Quli (2017) reported an average gross annual income of ' 27894.20 household $^{-1}$ annum $^{-1}$ composed of agriculture (36.24\%), NTFPs (17.18\%), wage labour (9.75\%), livestock (8.86\%), business/shopkeeping (8.72\%), timber (7.83\%), service $(6.78 \%)$, and others $(4.63 \%)$. This indicates that the commercialization of NTFPs is one of the main drivers for socio-economic development, poverty reduction and livelihood security of the tribes in Jharkhand. Forest resources are considered as a commodity of high value across the state as most of the locals are dependent for their daily subsistence needs mainly for food and fuelwood. Forests play an important role in the economic, cultural, and social lives and supporting rural livelihoods and food security in Jharkhand (Kumar and Saikia, 2020). The present study was conducted to keep all above facts under consideration and evaluate the socioeconomics and utilization pattern of major NTFPs in the study area. 


\subsection{Major NTFP's found in the state}

Jharkhand means 'forest region' where forests play a central role in the economic, cultural, and socio-political systems and the entire lives and livelihoods of a majority of the people revolve around forests and forestry. While forests have maintained the existence of tribal people for centuries, it can also, be said that tribals have traditionally protected the forest. In this way, there has been a symbiotic relationship between forests and tribals (Verma and Paul, 2016). Forest Survey of India (FSI, 2019) reported Shorea robusta (Nationalized), Buchanania Lanzan, Madhuca indica, Diospyrus melanoxylon ((Nationalized)) and Butea monosperma are the top five NTFPs of State Jharkhand. Tassar, Lac, Tamarind, Amla, Harra nut, Kusum, Karanj, Behera, etc. are other prominent NTFPs present in the state.

Livelihood enhancement interventions for any of living communities thus have to begin with a thorough understanding of the types, amounts, availability, and processing/storage/ marketing methods of the major NTFPs in their region (Kumar and Chaudhury, 2016). The Indian states, having the major NTFP resources exploited and traded during the last 3 years (2007-08 to 2009-10) are Madhya Pradesh, Chhattisgarh and Andhra Pradesh as shown below. The scale value of Jharkhand was 114.23 lakhs (Figure 1).

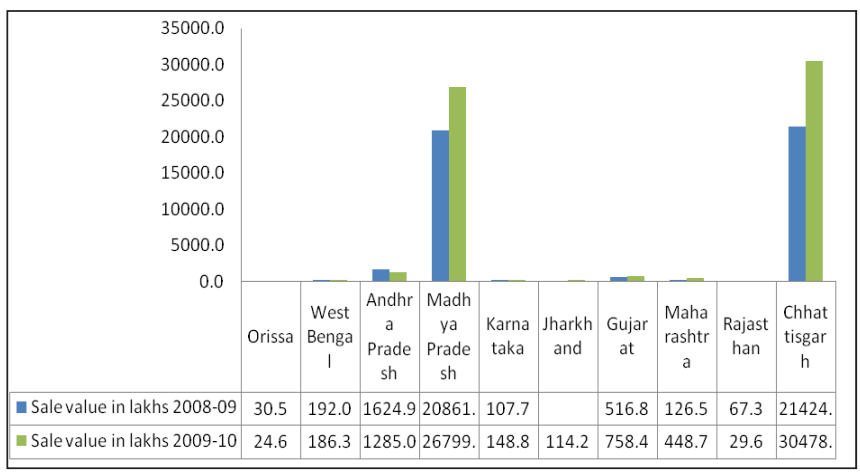

Figure 1: Sale Values of NTFP's for different states (Source: TRIFED report, September 2010)

\section{Materials and Methods}

\subsection{Study area}

The present study was conducted taking both primary and secondary approaches. Primary data has been gathered through field monitoring carried out in three villages in different districts of Jharkhand viz. Sahritola in Dumka district, Padampur in West Singhbhum district and Hakkadua in Khunti district. All the studied villages are culturally dissimilar and belong to different tribal communities. A brief description of the studied villages is given below Table 1.

\subsection{Survey and data collection}

Under the present study, data were collected through household surveys, trader surveys, focus group discussions, and collation of secondary information. Surveys were conducted with a sampling intensity of $15 \%$. Structured questionnaires were used to capture the primary information from forest village communities and small traders. The questions were grouped into the following categories i.e. production/collection, processing, storage, value addition, price, transport and sale. By and large, the focus of the survey was confined to (a) Volume available for each NTFP, (b) $\mathrm{HH}$ income enhancement through NTFP commercialization, (c) Share of NTFPs in $\mathrm{HH}$ income and (d) Major barriers associated with collection/ production, processing/storage and trade of NTFPs. The surveys were conducted by visiting each village and every fourth household. Interviews with a group of collectors (including men and women separately and together) were used for this purpose, along with other more participatory research methods. Besides, the household survey, small traders associated with concerned villages were also contacted for the survey. Market rates and market-chain was further cross-verified through visiting local traditional markets (locally called Hat) nearest to sample villages. Secondary information were gathered from various reports and consultation with expert organizations and local NGOs.

Table 1: Details of studied villages

\begin{tabular}{|c|c|c|c|c|c|c|}
\hline Village & Block & District & Division & Dominant community & Elevation & Coordinates \\
\hline Saharitola & Kathikund & Dumka & Santhal Pargana & "Santhal" & 180 & $\begin{array}{l}\text { N 24o24' } \\
\text { E 87o23' }\end{array}$ \\
\hline Padampur & Tonto & West Singhbhum & South Chhotanagpur & “Ho" & 431 & $\begin{array}{l}\text { N 22o21' } \\
\text { E 85o41' }\end{array}$ \\
\hline Hakkaduwa & Khunti & Khunti & Kolhan & "Munda" & 570 & $\begin{array}{l}\text { N 23006' } \\
\text { E 85o26' }\end{array}$ \\
\hline
\end{tabular}

\subsection{Data analysis}

Data were computed and analyzed qualitative and quantitative and represented for each quantitative aspect. Tabulation and presentation of data were carried out to arrive at a clear picture of the dynamics surrounding potential NTFPs in the selected villages. The market report for each prioritized NTFP in each selected area was also recorded. The basic marketing chain for each product from primary collectors to identify 
markets was also analyzed using quantitative data supported by qualitative observations.

\section{Results and Discussion}

\subsection{NTFPs resource}

The dependence of sample households for subsistence and sale was considerable and enveloping across studied villages. The NTFPs collected by sample households in the study areas were categorized into: a) NTFP for consumption only, b) NTFP for sale only and c) NTFP for both consumption and sale. The maximum number of NTFPs were recorded in Padampur (25) followed by Sahritola (22) and Hakkadua (19) (Box-1).

BOX-1. NTFPs resources and their consumption pattern

(' $C$ ' Consumption, 'S' Sale, ' $H$ ' High volume either consumption or sale)

Saharitola: Madhuca indica (flowers) ${ }^{\mathrm{C}+\mathrm{S}+\mathrm{H}}$, Madhuca indica (seeds) $^{\mathrm{C}}$, Tamarindus indica (Fruit pulp) ${ }^{\mathrm{C}+\mathrm{S}+\mathrm{H}}$, Milletia pinnata (seeds) ${ }^{\mathrm{C}}$, Tasar ${ }^{\mathrm{S}+\mathrm{H}}$, Bamboo ${ }^{\mathrm{C}}$, Diospyros melanoxylon (leaves) $^{\text {s }}$, Syzygium cumini (fruits) ${ }^{c}$, Mangifera indica (fruits) c, Artocarpus heterophyllus (fruits) ${ }^{\mathrm{c}+\mathrm{s}}$, Moringa oleifera (leaves+pods) ${ }^{\mathrm{C}}$, Aegle marmelos (fruits) ${ }^{\mathrm{C}}$, Shorea robusta (leaves) $^{\mathrm{C}}$, Bombax ceiba (cotton) ${ }^{\mathrm{S}+\mathrm{H}}$, Honey $^{\mathrm{C}}$, Mushroom ${ }^{\mathrm{C}}$, Wild date palm (fruits) ${ }^{\mathrm{C}+S+\mathrm{H}}$, Wild date palm (leaves) ${ }^{\mathrm{C}+\mathrm{S}+\mathrm{H}}$, Wild Tubers ${ }^{c}$, Wild medicinal plants ${ }^{c}$, Wild Bitter Gourd (fruits) ${ }^{\mathrm{c}+\mathrm{s}}$, Operculina turpethum (Nisoth) ${ }^{\mathrm{s}}$.

Padampur: Madhuca indica (flowers) ${ }^{\mathrm{C}+\mathrm{S}+\mathrm{H}}$, Madhuca indica (seeds) ${ }^{\mathrm{C}}$, Tamarindus indica (Fruit pulp) ${ }^{\mathrm{C}+\mathrm{s}+\mathrm{H}}$, Milletia pinnata (seeds) ${ }^{\mathrm{C}+\mathrm{S}+\mathrm{H}}$, Bamboo $^{\mathrm{C}}$, Diospyros melanoxylon (leaves) ${ }^{\mathrm{s}}$, Syzygium cumini (fruits) ${ }^{\mathrm{C}+\mathrm{S}}$, Mangifera indica (fruits) ${ }^{\mathrm{C}}$, Artocarpus heterophyllus (fruits) ${ }^{\mathrm{C}+\mathrm{s}+\mathrm{H}}$, Moringa oleifera (leaves+pods) c, Aegle marmelos (fruits) ${ }^{c}$, Terminalia chebula (fruits) ${ }^{\mathrm{C}}$, Terminalia bellerica (fruits) ${ }^{\mathrm{C}}$, Buchanania lanzan (seeds) ${ }^{\mathrm{S}+\mathrm{H}}$, Shorea robusta (leaves) ${ }^{\mathrm{C}}$, Azadirachta indica (seeds) ${ }^{\mathrm{C}}$, Wild cashew $^{\mathrm{S}}$, Honey $^{\mathrm{C}}$, Mushroom ${ }^{\mathrm{C}}$, Custard apple ${ }^{\mathrm{C}+\mathrm{S}+\mathrm{H}}$, Bauhinia variegata (leaves) ${ }^{c}$, Wild Tubers ${ }^{c}$, Wild medicinal plants ${ }^{c}$, Wild Bitter Gourd (fruits) ${ }^{\mathrm{c}+\mathrm{s}}$.

Hakkadua: Madhuca indica (flowers) ${ }^{\mathrm{C}+\mathrm{S}+\mathrm{H}}$, Madhuca indica (seeds) ${ }^{\mathrm{C}}$, Tamarindus indica (Fruit pulp $)^{\mathrm{C}+\mathrm{S}+\mathrm{H}}$, Milletia pinnata (seeds) ${ }^{\mathrm{C}+\mathrm{S}+\mathrm{H}}, \mathrm{Lac}^{\mathrm{S}+\mathrm{H}}$, Bamboo $^{\mathrm{C}}$, Diospyros melanoxylon (leaves) $^{\mathrm{s}}$, Diospyros melanoxylon (fruits) ${ }^{\mathrm{C}}$, Syzygium cumini (fruits) ${ }^{\mathrm{C}}$, Mangifera indica (fruits) ${ }^{\mathrm{C}+\mathrm{S}+\mathrm{H}}$, Mangifera indica

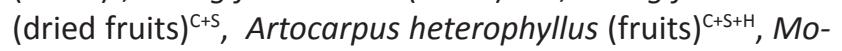
ringa oleifera (leaves+pods) ${ }^{C}$, Buchanania lanzan (seeds) ${ }^{\mathrm{S}+\mathrm{H}}$, Shorea robusta (leaves) ${ }^{\mathrm{C}}$, Honey ${ }^{\mathrm{C}}$, Mushroom ${ }^{\mathrm{C}}$, Custard apple $^{\mathrm{c}+\mathrm{s}}$, Wild medicinal plants ${ }^{\mathrm{c}}$, Wild Bitter Gourd (fruits) ${ }^{\mathrm{c}+\mathrm{s}}$.

The numbers of NTFPs solely collected for sale were very few; 4 in Sahritola, 3 in Padampur, and 3 in Hakkadua. Maximum numbers of NTFPs were consumed at the household level. 6-7 commodities were collected for consumption and sale. The maximum number (7) of high volume products were recorded in Hakkadua whereas in Saharitola and Padampur, 6 products show high volume (Figure 2).

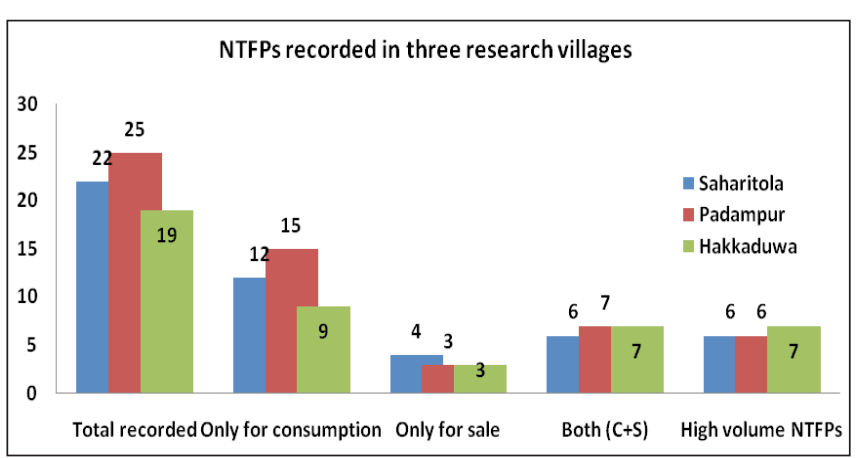

Figure 2: NTFPs collection in three research villages

\subsection{Contribution of NTFPs in tribal economy}

As far as the household income is concerned, it ranges from 20,000 ₹ $\mathrm{hh}^{-1} \mathrm{yr}^{-1}$ in Padampur to 40,000 ₹ $\mathrm{hh}^{-1} \mathrm{yr}^{-1^{-1}}$ in Sahritola. The maximum portion of household income comes from NTFPs in Saharitola and Padampur whereas, maximum income in Hakkaduwa village generated through off-farm activities (labor/MNREGA) followed by NTFPs and salary/ pension (Table 2).

Table 2: Income (INR hh-1 $\mathrm{yr}^{-1}$ ) generated through different activities including NTFP in studied villages

\begin{tabular}{lcccccc}
\hline Villages & NTFP & $\begin{array}{c}\text { Agri- } \\
\text { culture }\end{array}$ & O A & AH & SP & Total \\
\hline Saharitola & 19818 & 3625 & 2400 & 1063 & 12250 & 39155 \\
Padampur & 11447 & 1500 & 5300 & 780 & 500 & 19527 \\
Hakkadua & 6718 & 0 & 7600 & 200 & 6000 & 20518
\end{tabular}

OA: Off-farm activities; AH: Animal husbandry; SP: Salary and pension

The contribution of income from different activities in different villages is exhibited in Figure 3. The highest income proportion through NTFP's was recorded from Padampur (59\%) followed by Saharitola (51\%) and Hakkadua (33\%). In Hakkaduwa, the highest (37\%) share of income comes from off-farm activities.

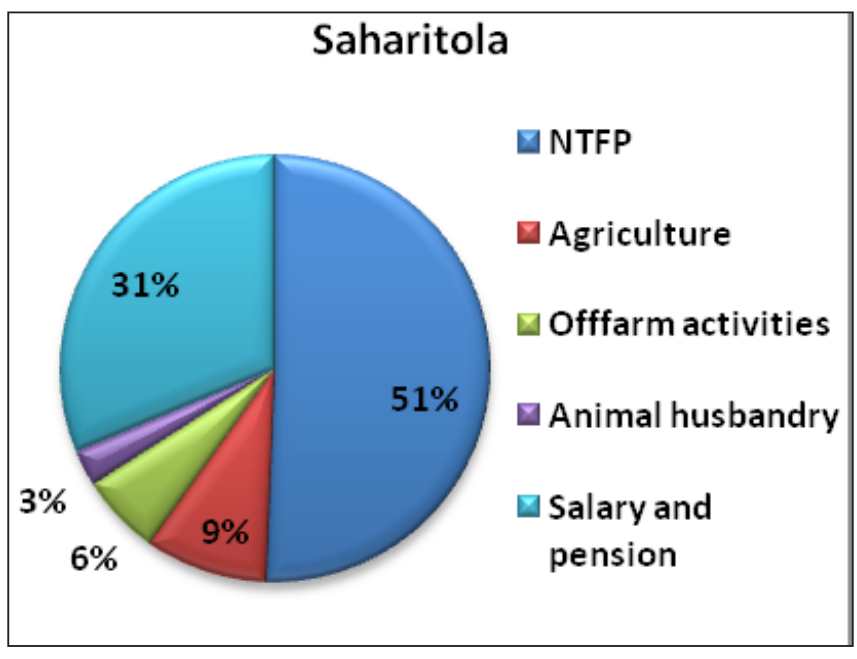

Figure 3: Continue... 

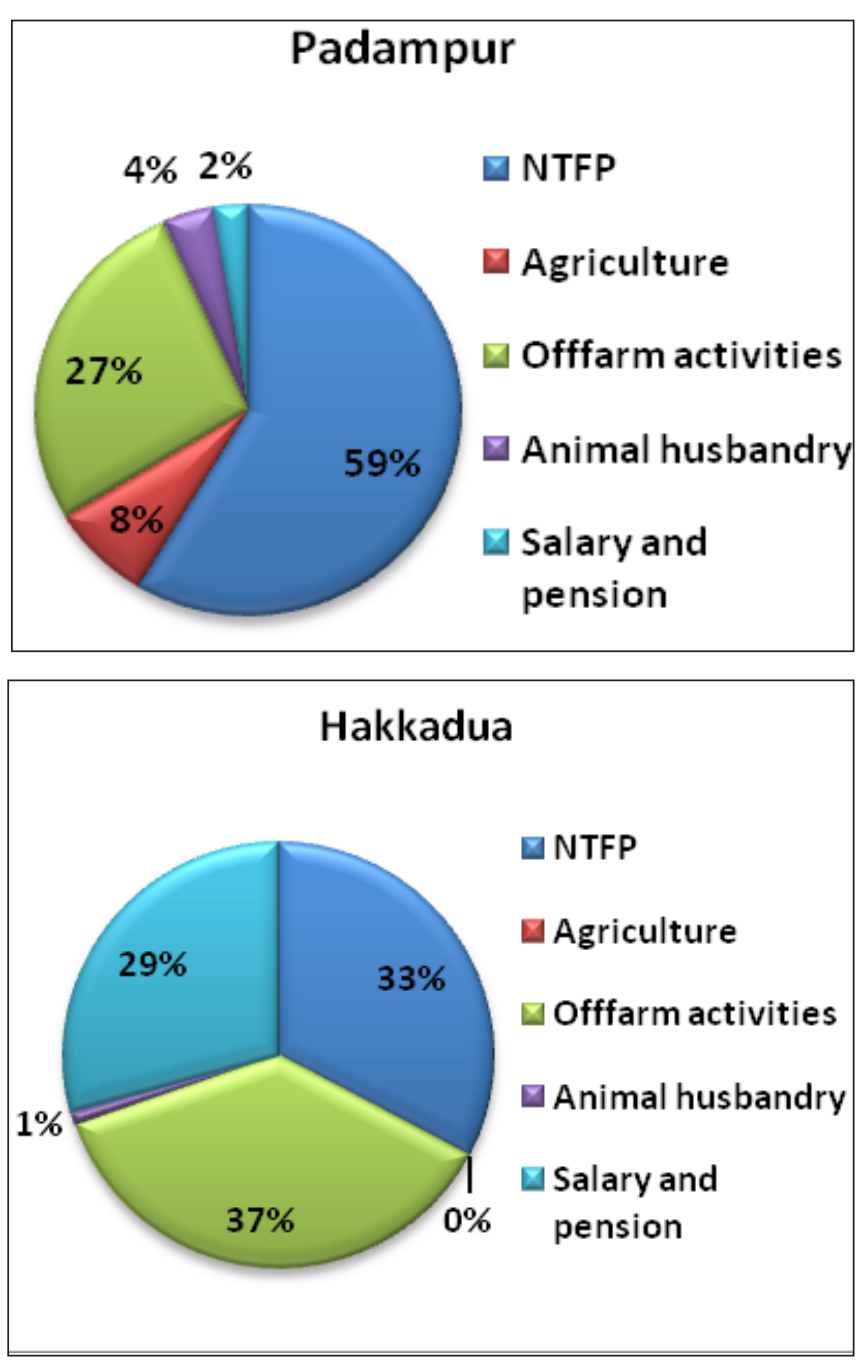

Figure 3: Contribution (\%) of NTFPs in average household income
The numbers of NTFPs solely collected for sale were very few; 4 in Sahritola, 3 in Padampur and 3 in Hakkadua. Maximum numbers of NTFPs were consumed at the household level. 6-7 commodities were collected for consumption and sale. The maximum number (7) of high volume products were recorded in Hakkadua whereas in Saharitola and Padampur, 6 products show high volume (Figure 2).

Income from potential NTFPs was also investigated in all three studied villages. The highest proportion of NTFPs household income was received from commercial Tasar $\left(15,913 \mathrm{HH}^{-1} \mathrm{yr}^{-1}\right)$ in Sahritola, Mahua $\left(3,940 \mathrm{HH}^{-1} \mathrm{yr}^{-1}\right)$ in Padampur and Lac $\left(4,950 \mathrm{HH}^{-1} \mathrm{yr}^{-1}\right)$ in Hakkaduwa. Mahua is the only commodity emerged as a potential NTFP in all three studied villages (Table 3).

If we compare the income proportion of different NTFPs, 81\% of total income generated from the NTFPs comes from the Tasar cultivation and allied NTFP commodities in Saharitola. Mahua emerged the biggest income contributor (34\%) in Padampur whereas, Lac contributed around $74 \%$ of income in Hakkaduwa. Contribution of others/lesser volume NTFPs is $10 \%$ in Padampur (Figure 4 ).

\subsection{Seasonality of collection of NTFPs}

People of Sahritola invest around 135 days $\mathrm{yr}^{-1}$ in the collection of NTFP's followed by Hakkaduwa (133 days $\mathrm{yr}^{-1}$ ) and Padampur (98 days $\mathrm{yr}^{-1}$ ). It might be due to a well-organized system of Tasar and Lac in Saharitola and Hakkaduwa, respectively. The average time spend under NTFP's commercial activities is $5.09,4.02$ and 4.04 hours day ${ }^{-1}$ in Saharitola, Padampur and Hakkaduwa, respectively. All the villages are forest fringe villages, on average 2.54, 2.11 and $2.34 \mathrm{Km}$ trips are made in a day for the collection of NTFPs in Saharitola, Padampur and Hakkaduwa, respectively. In most of the cases, two

Table 3: Income (₹ $\mathrm{hh}^{-1} \mathrm{yr}^{-1}$ ) generated through potential NTFPs collected/produced in studied villages

\begin{tabular}{|c|c|c|c|c|c|c|c|c|c|c|}
\hline \multirow[t]{2}{*}{ Species } & \multirow[t]{2}{*}{ Unit } & \multicolumn{3}{|c|}{ Saharitola } & \multicolumn{3}{|c|}{ Padampur } & \multicolumn{3}{|c|}{ Hakkaduwa } \\
\hline & & $\begin{array}{c}\text { Yield } \\
\left(\mathrm{HH}^{-1} \mathrm{yr}^{-1}\right)\end{array}$ & $\begin{array}{c}\text { Sale } \\
\text { price (₹) }\end{array}$ & $\begin{array}{c}\text { Income } \\
\text { (₹) }\end{array}$ & $\begin{array}{c}\text { Yield } \\
\left(\mathrm{HH}^{-1} \mathrm{yr}^{-1}\right)\end{array}$ & $\begin{array}{l}\text { Sale price } \\
\text { (₹) }\end{array}$ & $\begin{array}{c}\text { Income } \\
\text { (₹) }\end{array}$ & $\begin{array}{c}\text { Yield }\left(\mathrm{HH}^{-1}\right. \\
\left.y \mathrm{r}^{-1}\right)\end{array}$ & $\begin{array}{l}\text { Sale price } \\
\text { (₹) }\end{array}$ & $\begin{array}{c}\text { Income } \\
\text { (₹) }\end{array}$ \\
\hline Tasar (C) & Goti & 8375 & 1.9 & 15913 & - & - & - & - & - & - \\
\hline Mahua & $\mathrm{Kg}$ & 21 & 20 & 420 & 197 & 20 & 3940 & 35.5 & 22 & 781 \\
\hline Tamarind & $\mathrm{Kg}$ & - & - & - & 168 & 19 & 3192 & 20 & 18 & 360 \\
\hline Lac & $\mathrm{Kg}$ & - & - & - & 7 & 450 & 3150 & 11 & 450 & 4950 \\
\hline Karanj & $\mathrm{Kg}$ & - & - & - & - & - & - & 45 & 13 & 585 \\
\hline Sal leaves & $\begin{array}{l}\text { bun- } \\
\text { dle }\end{array}$ & 175 & 2.5 & 437.5 & - & - & - & - & - & - \\
\hline Tasar (P) & Goti & 5000 & 0.6 & 3000 & - & - & - & - & - & - \\
\hline
\end{tabular}

C- Commercial, P- Pierced

people from a household go for collection and often in groups comprising other villagers. The average number of NTFPs collected by the household was highest (5.40) in Hakkaduwa followed by Padampur (4.90) and Saharitola (2.87) (Table 4).

\subsection{Prioritization of NTFPs}

In the process of identification of potential NTFPs for future development, we used parameters for prioritization of the species as (a) NTFP income share of the species (b) Resource 

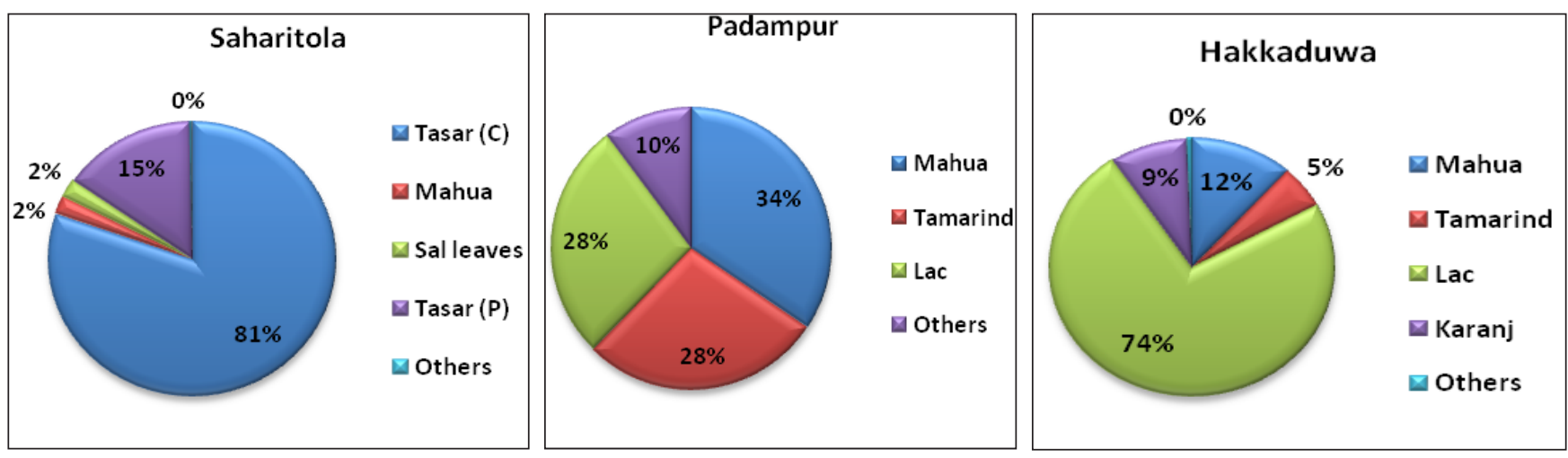

Figgure 4:.Contribution (\%) of potential NTFPs

\begin{tabular}{lccccc}
\hline Table 4: Days involved, time taken, distance covered for collection of NTFPs in studied villages \\
\hline Village & $\begin{array}{c}\text { Days involved in } \\
\text { collection (year- }{ }^{-1} \text { ) }\end{array}$ & $\begin{array}{c}\text { Time consumed in collection/ } \\
\text { commercial activities (hrs day- }{ }^{-1} \text { ) }\end{array}$ & $\begin{array}{c}\text { Distance cov- } \\
\text { ered (Km day- }\end{array}{ }^{-1}$ ) & $\begin{array}{c}\text { Person involved } \\
\text { in collection }\end{array}$ & $\begin{array}{c}\text { Number of NTFPs } \\
\text { collected }\left(\mathrm{HH}^{-}{ }^{-}\right)\end{array}$ \\
\hline Saharitola & 135 & 5.09 & 2.54 & 1.57 & 2.87 \\
Padampur & 98 & 4.02 & 2.11 & 1.76 & 4.90 \\
Hakkadua & 133 & 4.04 & 2.34 & 1.68 & 5.40 \\
\hline
\end{tabular}

availability of the species. The pia diagram (Figure 5 and 6) shows that Lac has added maximum (42\%) to the income obtained from NTFPs followed by Mahua (29\%), Tamarind (19\%) and Karanj (3.14\%).

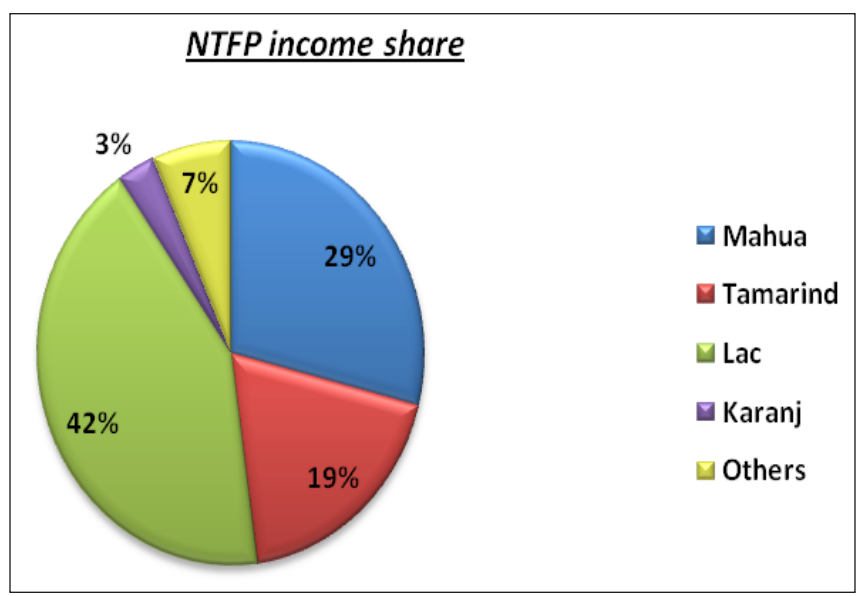

Figure 5: Average income share of different NTFPs in three studied villages

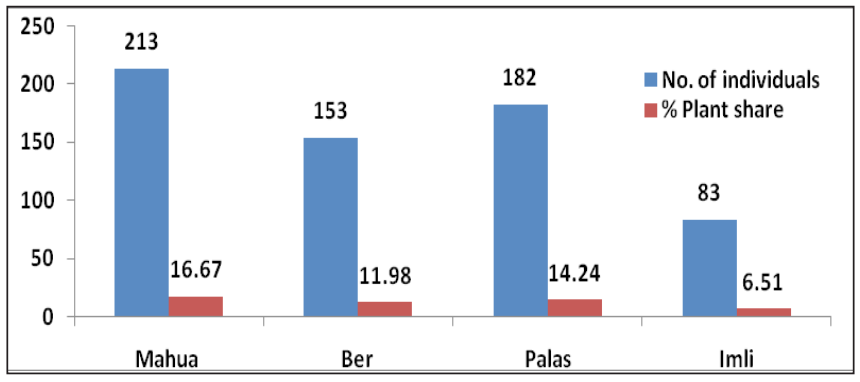

Figure 6: Average potential NTFP resources in three studied villages
We further investigated the resource potential of various NTFPs present in the village by doing tree resource inventory Thus, we identified Mahua (Madhuca indica), Lac and Tamarind (Tamarindus indica) which adds significantly to household income and have abundant resource availability.

\subsection{Profile of Prioritize NTFPs}

\subsubsection{Mahua (Madhuca indica)}

Mahua (Madhuca indica) is a medium to large size tree often referred to as "Tree of the Poors" as it is a major source of food and seasonal income in tribal regions. The nutraceutical properties of mahua flowers are well known and also better as compared to other food items. It is predominantly used for making liquor. Seeds of mahua are used for the extraction of oils, which is further used for many purposes such as making soaps, bio-fuel and whereas oil cakes and leaves are used as a nutritious feed for cattle.

\subsubsection{Value chain of mahua}

Mahua is the key NTFP in Jharkhand. The present study revealed a share of $29 \%$ of NTFP income generated through mahua. The tree has its cultural and aesthetic values in tribal culture and therefore conserved by the villagers. The tree is often found in the farm, community land and forests. Most of the trees occurring near the settlements are recognized as being associated with a family but the trees in the forest are common property resources. In most of the cases, immediate sale of mahua is being practiced among tribal people for instant cash requirements (termed as 'distress selling') during the low activity months. In the winter months of January and February, Mahua is bought back by the villagers for domestic use at prices higher than they have sold (Figure 7).

\subsubsection{Tamarind (Tamarindus indica)}

Tamarind (Tamarindus indica), locally called 'Imli' is 


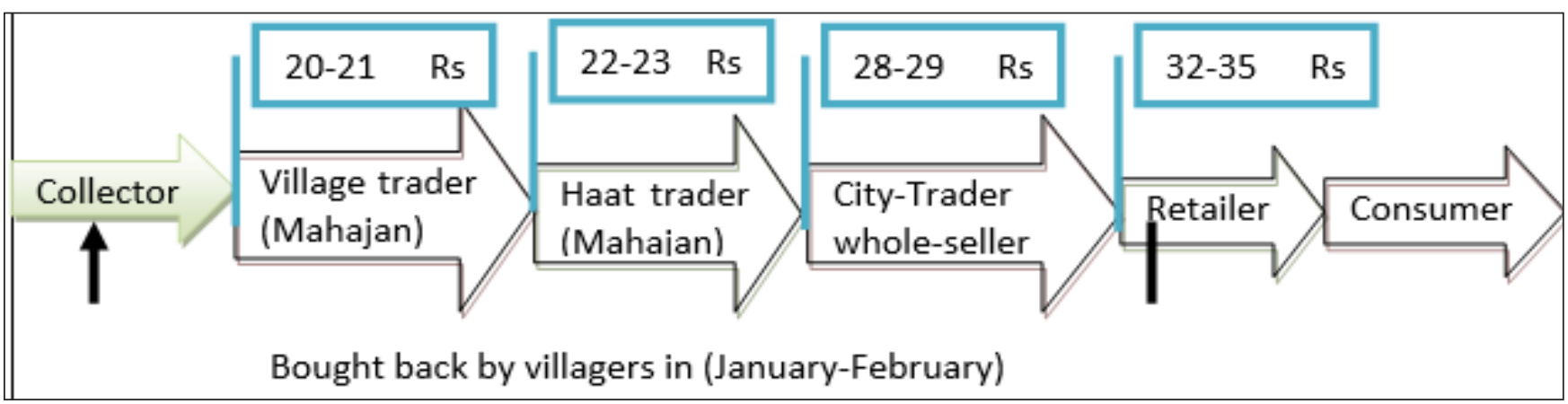

Figure 7: Market-Chain Analysis and margin of benefits at different nodes

distributed throughout Indian States and Madhya Pradesh, Andhra Pradesh, Uttar Pradesh, Karnataka, Tamil Nadu and Orissa are the major producer states of tamarind in India. Jharkhand is one of the major producers of tamarind because of abundant resource availability. Most of the tamarind traded from the Jharkhand and southern Indian states; Andhra Pradesh, Tamilnadu. Tamarind has various uses. The pulp of tamarind has a sweet-sour-spicy flavor and is extensively used for flavoring. It is widely used as preservative and flavoring in desserts and dishes, preparation of pickles, and juice. Along with this, tamarind seed powder is also used to produce starch, cattle feed, paint, gum, and plywood industry.

\subsubsection{Value chain of tamarind}

Tamarind is sold to the market both raw and seedless. However, the practice of selling raw tamarind prevalent in the studied villages, the practice of drying was also observed largely to enhance the self-life before selling. The studied lack of processing practices of tamarind, de-seeding of tamarind at household level and makes it more consumer-friendly (Figure 8).

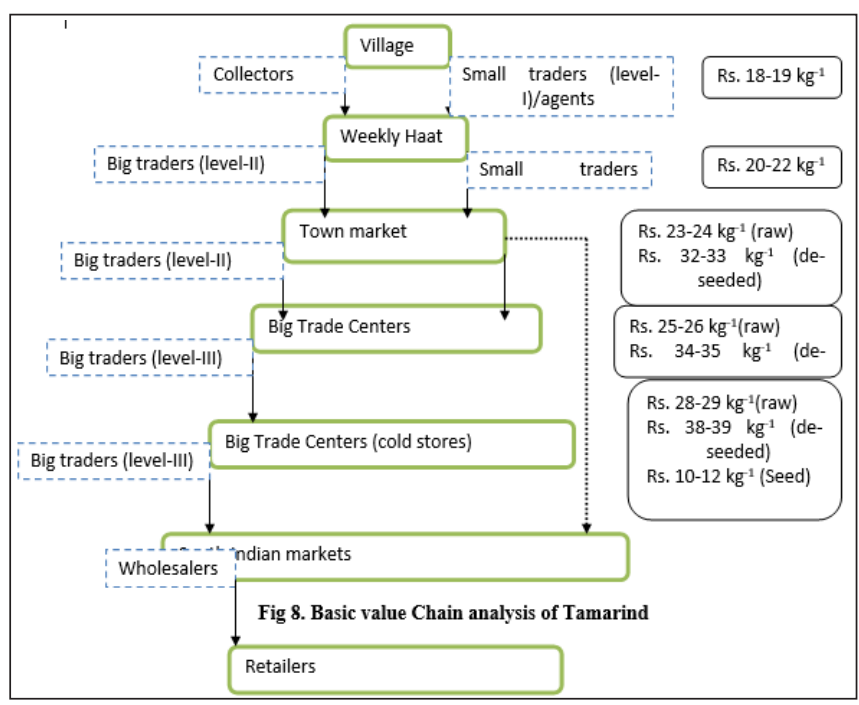

Figure 8: Basic value Chain analysis of Tamarind

\subsection{3. $L a c$}

Lac is a natural resin secreted by an insect known as Kerria lacca (Kerr.) which thrives on the tender twigs of specific host trees, viz. Dhak (Butea monosperma), Ber
(Zizyphus mauritiana), Kusum (Schleichera oleosa), Semialata (Flemingia semialata), Ficus sp., etc. In India, lac cultivation is widely practiced in the states of Jharkhand, West Bengal, Chhattisgarh, Madhya Pradesh, Orissa, Maharashtra and parts of Uttar Pradesh, Andhra Pradesh, Gujrat. India is the largest producer of lac in the world, accounting for about 50\%-60\% of the total world lac production and about $57 \%$ of total lac produced from the state Jharkhand. Lac resin being natural, biodegradable and nontoxic, finds applications in food, textiles, and pharmaceutical industries in addition to surfacecoating, electrical, and other fields. It is used either in the form of a solution in some solvent or as a mixture with other substances. Lac finds a wide variety of applications in paint, electrical, automobile, cosmetic, adhesive, leather, wood finishing and other industries. Earlier about half of the total output was consumed in the gramophone industry. Several other products are produced from the lac i.e. Dyes, Bangles, Varnishes, Paints, Polices, Jewelry, Toys, and Handicraft.

Value chain of Lac

The basic value chain of lac is given in Figure 9.

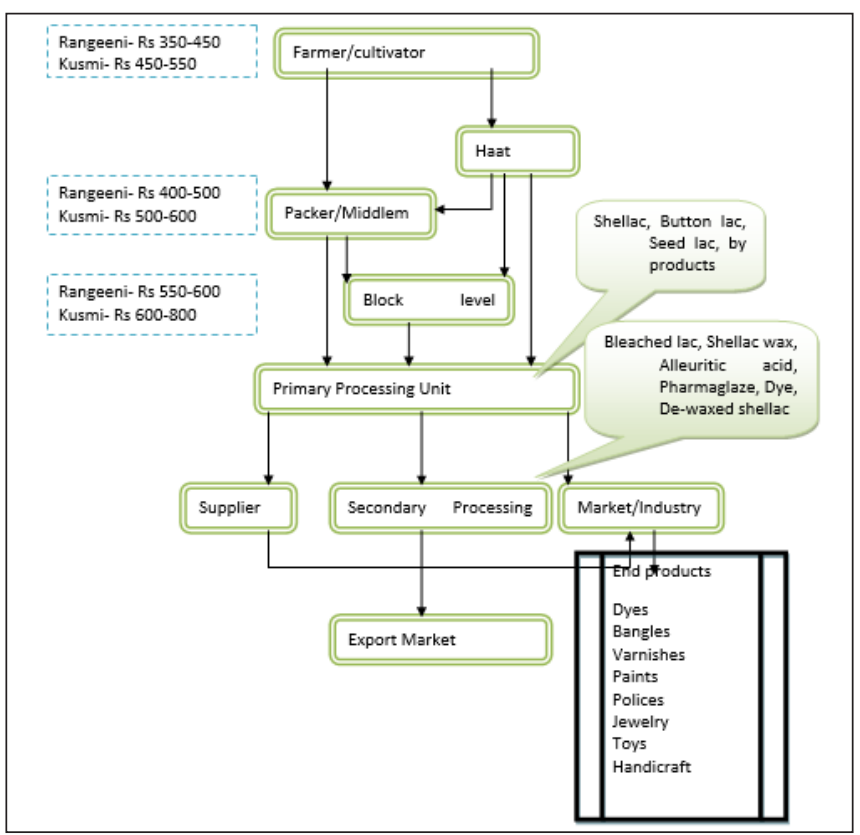

Figure 9: Basic value chain of Lac 
In this study, the dependence on forests is either for basic household requirements such as fuelwood and fodder or for contribution in household income in rural areas. Similar accounts have been reported in other areas across the Himalayan region (Naidu, 2011; Rayamajhi et al., 2012, Maren et al., 2014).

\section{Conclusion}

The present study reveals a considerable dependence on NTFP for the subsistence of rural people of the state of Jharkhand. As high as $48 \%$ of the total household income is generated through the sale of NTFP's in the studied villages, moreover majority of NTFP's provide income in the most deprived months of the year when agriculture and allied activities are minimal. While the returns from the cultivation of Tassar and Lac are high and provide returns almost round the year, Mahua has emerged as one of the important NTFP owing to the seasonality of the products and also due to cultural significance and ranked topmost through this analysis for further interventions. Mahua provides the most crucial income during the summer and monsoon months when income generation possibilities are limited and the substantial amount of time and upfront cost is required for agriculture.

\section{Acknowledgement}

The Author is thankful to Sir Ratan Tata Trust, Dehradun, Uttarakhand for providing financial support and Dr. R. Thadani, CEDAR, Dehradun, Uttarakhand for given the opportunity to carry out this study.

\section{References}

Bedia, S., 2014. Study on the forest based livelihood for the selected tribal population of Ranchi district of Jharkhand. B.Sc. Dissertation, Unpublished. Faculty Centre for Integrated Rural and Tribal Development and Management, School of Agriculture and Rural Development. Ranchi, India.

FSI, 2019. The State of Forest Report-2019. Forest Survey of India, Dehradun-Uttarakhand.

Islam, M.A., Quli, S.M.S., 2017. The Role of Non-Timber Forest Products (NTFPs) in Tribal Economy of Jharkhand, India. International Journal of Current Microbiology and Applied Sciences 6, 2184-2195.

Kumar, R., Saikia, P., 2020. Forest Resources of Jharkhand,
Eastern India: Socio-economic and Bio-ecological Perspectives. DOI-10.1007/978-3-030-32463-6_4, In book: Socio-economic and Eco-biological Dimensions in Resource use and Conservation-Strategies for Sustainability, Chapter:4, Publisher: Springer Nature Switzerland AG.

Kumar, S., Chaudhury, A., 2016. Enhancement of livelihood activities through non-timber forest products: a study in Jharkhand's Ranchi and Simdega districts. Jharkhand Journal of Development and Management Studies 14, 6919-6930.

Maren, I.E., Bhattarai, K.R., Chaudhary, R.P., 2014. Forest ecosystem services and biodiversity in contrasting Himalayan forest management systems. Environmental conservation $41,73-83$.

Minz, D., Hansda, D.M., 2010. "Encyclopaedia of Scheduled Tribes in Jharkhand". books.google.co.in. Kalpaz Publication Delhi.

Naidu, S.C., 2011. Access to benefits from forest commons in the Western Himalayas. Ecological Economics 71, 202-210.

Rayamajhi, S., Smith-Hall, C., Helles, F., 2012. Empirical evidence of the economic importance of Central Himalayan forests to rural households. Forest Policy and Economics 20, 25-35.

Shaanker, R.U., Ganeshaiah, K.N., Krishnan, S., Ramya, R., Meera, C., Aravind, N.A., Kumar, A., Rao, D., Vanaraj, G., Ramachandra, J., Gauthier, R., Ghazoul, J., Poole, N., Reddy, B. V.C., 2004. Livelihood gains and ecological costs of non-timber forest product dependence: assessing the roles of dependence, ecological knowledge and market structure in three contrasting human and ecological settings in South India. Environmental Conservation 3, 242-253.

Tribal Cooperative Marketing Development Federation of India Limited (TRIFED). Report, September 2010. http:// trifed.in/trifed/(S(vnshnere1mpr4j4z1d4j3xra))/default. aspx.

Verma, S.K., Paul, S.K., 2016. Sustaining the non-timber forest products (NTFPs) based rural livelihoods of tribals in Jharkhand: issues and challenges. Jharkhand Journal of Development and Management Studies 14, 6865-6883. 